\title{
Headache, migraine, brain lesion and MRI study
}

\author{
N Radojkovic Gligic*, R Amanovic Curuvija, K Kacar \\ From The European Headache and Migraine Trust International Congress \\ London, UK. 20-23 September 2012
}

\section{Introduction}

Many people have primary and often disabling headaches. The common forms are migraine and tension headache. Headache in general and migraine in particular have been increased risk if comorbidities. The migraine with aura is a marker for increased risk of cerebrovascular disease, specifically stroke. Migraine has been associated with a variety of structural brain lesion, including silent infarct, like lesion in the postertior circulation territory and with white matter hyperintensities.

\section{Methods}

Of the 120 participants with brain scans, we compared the means of continuous characteristics and frequency of categorical characteristics of participants according to the headache status. We run age adjusted multivariable models for total and localised white matter hyper intensities. The multivariable models controlled for age (continuous) sex, history of hypertension, smoking(ever, never) body mass index, alcohol consumption, serum total cholesterol level and family history of severe headache.

\section{Results}

Characteristics of lesions were visualized simultaneusly in axial, coronal, and sagital planes. A brain infarct was defined as focal lesion of $3 \mathrm{~mm}$ or more with the same signal characteristical as cerebrospinal fluid on both $\mathrm{T} 1$ and $\mathrm{T} 2$ weighted sequences, and these were discriminated from dilated vascular space (Virchow-Robin space) according to their shapes and locations. We applied this definition to all lesion irrespective of location. We distinguished the infarcts in the cerebellum, brain stem and in other locations.

\section{Discussion}

In this population we found that any lifetime history of severe headaches was associated with an increased risk of higher volumes of total, deep, and periventricular

Hospital for cerebrovascular desease St. Sava, Serbia and Montenegro white matter hyperintensity.-for migraine and non migraine headache. Participants who had migraine with aura in general was associated with brain infarcts.

Published: 21 February 2013

\section{References}

1. Rocca MA, Columbo B, Pratesi A, Comi G, Flippi M: A magnezition transfer imaging study of the brain in patients with migraine. neurology Pub med; 2000.

2. Silbert LC, nelson C, Howieson DB, Moore MM, Kaye JA: Impact of white matter hyperintensity volume progression on rate of cognitive and motor decline. Neurology pub med; 2008.

3. Tobias Curt: headache, migraine and structural lesion and function : popilation based Epidemiology of vascular Ageing MRI study. Pub med; 2011.

doi:10.1186/1129-2377-14-S1-P102

Cite this article as: Radojkovic Gligic et al:: Headache, migraine, brain lesion and MRI study. The Journal of Headache and Pain 2013 14(Suppl 1): P102.

\section{SpringerOpen $^{\odot}$}

C 2013 Radojkovic Gligic et al; licensee Springer. This is an Open Access article distributed under the terms of the Creative Commons Attribution License (http://creativecommons.org/licenses/by/2.0), which permits unrestricted use, distribution, and reproduction in any medium, provided the original work is properly cited.
Submit your manuscript to a SpringerOpen ${ }^{\circ}$ journal and benefit from:

- Convenient online submission

- Rigorous peer review

- Immediate publication on acceptance

- Open access: articles freely available online

- High visibility within the field

Retaining the copyright to your article

Submit your next manuscript at $>$ springeropen.com 